\title{
ACCIDENT LIABILITY RECONSIDERED: THE IMPACT OF LIABILITY INSURANCE
}

\author{
FLEMING JAMES, JR. $\dagger$
}

I

DURING the formative period of most of the current doctrines of negligence law, liability in tort was looked on as shifting a loss that had already occurred from one individual to another-generally from the person who suffered the loss to the person who caused it. It is against the background of this way of looking at things that nearly all of our conventional reasoning about the objectives of tort law has developed and that nearly all of our conclusions have been drawn and our rules formulated. But society has no interest in the mere shifting of a loss between individuals just for the sake of shifting it. The loss, by hypothesis, has already happened. $A$ has been killed, or his leg broken or his automobile smashed up. If the only question is whether $B$ shall be made to pay for this loss, any good that may come to society from having compensation made to one of its members is exactly offset by the harm caused by taking that amount away from another of its members. In that view of the problem there had to be some additional reason for a defendant to compensate a plaintiff for his injury before society would compel compensation. These reasons might be (a) a feeling of what is fair or just; (b) a desire to discourage dangerous conduct, or of course a combination of both.

To a very considerable extent this last-named desire was tempered by a strong counter-desire not unduly to discourage enterprising affirmative activity - even when it was dangerous-because people were very much imbued with the idea that unfettered enterprise and activity in nearly all directions worked out through the laws of competition to promote the general good. And again, these matters of fairness and deterrence were all considered on the assumptions that plaintiff and defendant were alone involved and that what happened between them was the real issue- that tort liability was paid for out of the defendant's own pocketbook. This focussed attention on the moral quality of the conduct of the individual participants in the accident. The net result was the general principle of no liability without fault.

There is however an altogether different approach to tort law. Human failures in a machine age cause a large and fairly regular-though probably reducible-toll of life, limb, and property. As a class the victims of these accidents can ill afford the loss they entail. The problem of decreasing this toll can best be solved through the pressure of safety regulations with penal and licensing sanctions, and of self-inter-

$\doteqdot$ Lafayette S. Foster Professor of Law, Yale Law School. 
est in avoiding the host of non-legal disadvantages that flow from accidents. But when this is all done, human losses remain. It is the principal job of tort law today to deal with these losses. The best and most efficient way to do this is to assure accident victims of compensation, and to distribute the losses involved over society as a whole or some very large segment of it. Such a basis for administering losses may be called social insurance.

This at once brings in an important new element. For while no social good may come from the mere shifting of a loss, society does benefit from the wide and regular distribution of losses, taken alone. ${ }^{1}$ The administration of losses in this way may entirely change evaluations of what is fair. If a certain type of loss is the more or less inevitable by-product of a desirable but dangerous form of activity it may well be.just to distribute such losses among all the beneficiaries of the activity though it would be unjust to visit them severally upon those individuals who had happened to be the faultless instruments causing them. ${ }^{2}$

What I have termed the principle of social insurance has been openly accepted in one important branch of what used to be tort law-the field of industrial accident. For the rest, the older principles of tort

1. This comes about in the following ways:

(a) from the point of view of the individuals engaged in the activity which causes the loss, a certain, calculable, and reasonable cost is substituted for the chance of ruinous loss through liability. This removes a detriment to engaging in useful but dangerous activity. See Willett, The Economic Theory of Risk and Insurance 107 et seq. (1901); Kurp, Casualty Insurance 13-4 (1928).

(b) The victim, too, is protected from the risk of financial ruin or great financial shock. This is a direct benefit to society since the social good includes the sum of the good accruing to individuals. And it also benefits society indirectly by protecting it from the repercussions of irdividual ruin which are broader and more extreme than the dircet loss. See Report by Commitree to Study Compensation for Automobile Accidents 56, 66, 219, 220 (Columbia University Council for Research in the Social Sciences, 1932) (hereinafter referred. to as Columbla Report); 6 Publications of New York StATE Constitutional Convention Conmitree 580 et seq. (1938); Corstvet, The Uncompensated Accident and Its Consequences, 3 Law \& Contemp. Prop. 466 (1936); Douglas, Wage Earner Bankruptcies-State vs. Federal Control, 42 Yale L. J. 591,607 (1933); Douglas, Some Functional Aspects of Bankruptcy, 41 YALE L.J. 329, 340 (1932).

(c) Even where individual ruin and its wider consequences are not threatened, the cquitable and wide distribution of a loss is all to the good, for a man's bottom dollar is his most valuable dollar, and each dollar added to that has a decreasing value to him. So that if a loss equals 100 , less social disutility will result from letting one unit of it fall on cach of 100 people than from putting it all on one person. For a fairly simple exposition of the concept of marginal utility, see Wicksets, Lectures on Poutticst Economy 29 et seq. (1934).

2. Surely there is here at least as much of a moral point of view as in the "finult" basis of liability, "but it is social morality, and not personal blame which is involved." Prosser, Torts 21 (1941); Pound, The End of Law as Developed in Legal Rules and Doctrines, 27 HARv. L. Rev. 195, 233 (1914). See James, Contribution Among Joint Tortfeasors: A Pragmatic Criticism, 54 HARv. L. REv. 1156, 1158 (1941). 
liability based on fault remain on the surface and, as they are reflected in legal reasoning, remain pretty much the same although there have been peripheral extensions. ${ }^{3}$ But this lack of formal change in the main body of accident law is really misleading. Great changes are going on under the surface which have profoundly affected the operation and incidence of tort liability and the assurance of compensation.

Chief among the factors which have brought about this change is the prevalence of liability insurance-a device which was unlinown until practically the end of the last century. ${ }^{4}$ Legally, liability insurance was at first (and still largely is) regarded as an altogether irrelevant fact in the consideration of tort liability. It was a private contract of indemnity between the defendant and an outsider, by which the latter undertook to protect the insured from loss on account of his individual legal liability. As to the injured person it was res inter alios acta-or as the non-classically trained layman would put it, "none of his business." But whatever the orthodox legal notion, the fact of widely held insurance and the form and development of insurance policies and insurance practices have very greatly changed the way tort law actually works. What these things have done, in effect, is to introduce into our present system some of the aspects of a scheme of social insurance. This article will try to trace out and evaluate some of the ways in which this has happened. First we shall examine how liability insurance affects the incidence and distribution of loss under some of the existing rules of tort law; next we shall try to explore how the widespread holding of such insurance affects the matter of accident prevention; then we shall see how insurance policy developments have increased the assurance of compensation and have even modified some of the rules of liability. Finally we shall inquire into the way insurance company settlement practices affect the question of compensating the victims of today's accidents.

\section{II}

Of prime importance is the fact that wherever there is widely held insurance, tort liability no longer merely shifts a loss from one individual to another but it tends to distribute the loss according to the principles of insurance, and the person nominally liable is often only a conduit through whom this process of distribution starts to flow. This

3. Such as the increasing tendency towards allowing recovery for pre-natal injuries, Bonbrest v. Kotz, 65 F. Supp. 138 (D.D.C. 1946), 32 VA. L. Rev. 1203, 32 Con:r. L. Q. 609 (1947), and the growing liberality towards cases where there has been injury through fright or shock without impact. See Goodrich, Emotional Disturbontec os Legal Damage, 20 MIrce. L. REv. 497 (1922); Magruder, MYental and Emotional Disturlaree in the Laze of Torts, 49 Harv. L. Rev. 1033 (1936); and for an extreme case, Rasmussen v. Benson, 135 Neb. 232, 280 N.W. 890 (1938), 48 YALE L. J. 303.

4. Crobauge \& Redding, Casualty Insurantee 395 (1928); Arciveely, Illegolity as a Factor in Insurance, 41 CoL. L. KEv. 26, 28 (1941). 
does not at all mean that the loss disappears and does not have to be paid for. But it does mean that you ought to know who is paying for it, and in what proportions, before you can really see and evaluate what is going on even in terms of the fault principle. And it does mean that when courts talk and reason about a rule of law as though the judgment were to come out of the defendant's pocket, they are often thinking in terms of complete unreality. Further, this fact of insurance does mean that some of the benefits and values of social insurance are actually attained under our present system, and it opens up possibilities for their further pursuit to the extent that this is thought desirable. Surely at the very least it invites an appraisal of existing or proposed rules of law in terms of how they serve the possible objectives of social insurance as well as how they serve the fault principle. Such an ap. praisal, in turn, calls for a study which observes and traces out the way losses are paid and distributed in actual operation.

In many situations this study will reveal problems which are fairly simple to state. Any rule of law, for instance, which tends effectively to impose stricter liability on the insured motorist, or cuts down his defenses, permits some of the benefits of social insurance in the case of just so many more claims. ${ }^{5}$ The extra cost of paying these claims will not all be cast on the individuals who nominally incur them, but will be distributed over the whole group of policy holders carrying insurance on this type of risk. The questions then are: how much this extra cost will add to the premiums and whether on a balancing of this and other pertinent factors it is desirable or just to impose and distribute the extra cost in this way. Very few studies have been made of the cost in premium rates of a rule of law. ${ }^{6}$ Nor would an accurate study along this line be easy. The insurance companies themselves do not even try to find out what part of their losses is attributable to any given legal doctrine. Rates for a locality are computed on the basis of gross losses paid, and a multitude of factors (many of them nonlegal) go into making this a relatively high or low sum. ${ }^{7}$ But while

5. Other examples are the rules imposing strict liability for harm caused by some kinds of extra-hazardous activities, such as blasting; and rules like res ipsa loquitur which throw the burden of injury from unexplained accidents on those whose activities cause them.

6. In an interesting article reappraising the Missouri humanitarian rule in the light of present conditions, the differentials between automobile liability insurance rates in Missouri and some surrounding states are set out. McCleary, Bases of the Humanitarian Doctrine Reexamined, 5 Mo. L. Rev. 56, 87 (1940). These show that the Missouri rates are high, but it would be hard indeed to demonstrate just how much of this (if any) is attributable to the humanitarian doctrine.

7. Some of these are the tendency of local juries to give high verdicts (or low oncs, as the case may be); the extent to which ambulance chasing is organized; the extent to which the general population is "claim wise"; and the general standard of living in the community. For a suggestion of some non-legal factors causing the current pressure towards 
there is a painful lack of data for accurately measuring the money cost of a rule imposing stricter liability, a truer and more useful appraisal of the interests and policies involved in a decision will result from thinking through its implications in terms of distribution of losses through insurance ${ }^{8}$ rather than proceeding on the false and misleading assumption that the individual defendant pays the damages, when in so many cases he does not.

A specific situation of this kind where, in hard fact, the insurance factor is really the dominant one, yet where most (though not all) of the judicial reasoning ignores this factor and turns on considerations which the fact of insurance has really made quite irrelevant, is the field of intra-family suits for negligence. Recovery by the unemancipated minor child against his parent is almost uniformly denied for a variety of reasons which involve the integrity of the family unit and the family exchequer and the importance of parental discipline. ${ }^{9}$ But in truth, virtually no such suits are brought except where there is insurance. And where there is, none of these threats to the family exists at all. Other problems, to be sure, are raised, such as the very great ease of a dishonest but concerted assault by the family against the insurance company. And of course there is the deeper question whether such losses should be borne by the individuals suffering them (who happen to stand in close family relationship to the "wrongdoer,") or whether they should be distributed over the motoring public. But the conventional way of talking about the matter tends only to conceal these real problems and prevent intelligent consideration of them. All this has been ably pointed

higher rates, see 47 Best's Insurance News (Fire \& Cas. ed.) No. 11, p. 17 (1947) (hereinafter cited as Best's). Cf. Downs, Compulsory Insurance, 40 Best's No. 7, p. 21, 23 (1939) ; 48 Best's No. 3, p. 54 (1947).

8. A fairly early example of clear judicial thinking along this line is Mfartin v. New York \& N.E.R. Co., 62 Conn. 331, 25 A. 239 (1S92). Mrore recent examples are to be found in Escola v. Coca-Cola Bottling Co., 24 Cal.2d 453, 461, 150 P.2d 436, 440 (1944) (concurring opinion of Traynor, J.) ; Piper v. Epstein, 326 Ill. App. 400, 62 N.E2d 139 (1945) ; President \& Dir. of Georgetown College v. Hughes, 130 F.2d 810, 823, 824 (1942). The last two opinions cited treat the problem of immunity for charitable institutions where there is liability insurance. They come to opposite conclusions, but in each case the real problem is more clearly seen because it is thought of in the way here contended for. Cf. O'Connor v. Boulder Colorado Sanitarium Ass'n, 105 Colo. 259, 96 P.2d 835 (1939), 53 HARv. L. REv. 873 (1940), where the court appreciates the fact of insurance but ignores the probable effect of liability in the higher cost of insurance protection to charities.

9. A good example of this kind of thing is the majority opinion in Small v. MIorrison, 185 N. C. 577, 118 S.E. 12 (1923). An even more shocking decision is Lasechi v. Kabara, 235 Wis. 645, 294 N.W. 33 (1940). Here both parents were dead and their insurance carrier was made a party defendant as the Wisconsin practice allows, yet recover; by the children was denied. In Louisiana, however, the plaintiff's ability to procecd directly against the insurer has led its courts to look at fact rather than myth. Edwards v. Royal Indemnity Co., 182 La. 171, 161 So. 191 (1935). See Aloore, Dcfenses Arsilable to the Landlord's Insurer under Act 174 of 1932, 21 TULANE L. REv. 596 (1947). 
out in law review comment ${ }^{10}$ and in a thoughtfully realistic opinion of the New Hampshire court, ${ }^{11}$ but such instances are rare, at least as far as judicial treatment of the problem goes.

There are other situations in the field of torts where the indirect, but vital, effect of insurance has not, so far as I know, been much noticed or traced out. A great deal has been written by commentators, ${ }^{12}$ for example, and some by courts ${ }^{13}$ about the proper standard of conduct to be applied to infants when they are sued as defendants. There is respectable authority that they should not be held to the standard required of the reasonably prudent adult but that allowance should be made for their immaturity. ${ }^{14}$ If the assumption is that infants have to pay the damages assessed against them, this view is quite defensible. In the first place, it obviously is a further refinement and individualization of the fault principle because it tends more closely to make legal fault coincide with moral fault. And again, if we proceed on this same assumption, there would be some strong practical arguments against overburdening the development and learning of skills which ought to be encouraged in the young. But what would happen to these arguments if the assumption proved false-if infants do not have to pay damages assessed against them? ${ }^{15} \mathrm{~A}$ great deal of evidence points strongly to the conclusion that they do not. Till well along in the present century there was an almost complete dearth of actual judicial

10. McCurdy, Torts Between People in Domtestic Relafions, 43 HARv. L. REv. 1030 (1930).

11. Dunlap v. Dunlap, 84 N.H, 352, 150 A. 905 (1930). A similar decision is Lusk v. Lusk, 113 W. Va. 17, 166 S.E. 538 (1932).

12. Bohlen, Liability in Tort of Infants and Insane Persons, 23 Mrcr. L. Rev. (1924); Shulman, Standard of Care for Children, 37 YALE L. J. 618 (1928); HARPER, LAW of Torts \$282 (1933) ; Prosser, Torts 229 et seq., 1086 (1941) ; Salmond, Law of TORTs 61 (10th ed. 1945); see Terry, Negligence, 29 Harv. L. Rev. 40, 47 (1915).

13. The fullest judicial discussion appears in Charbonneau v. MacRury, 84 N.H. 501, 153 A. 457 (1931), 15 Mins. L. REv. 834, 79 U. of PA. L. REv. 1153. Other cases are Neal v. Gillett, 23 Conn. 437 (1855); Briese v. Maechtle, 146 Wis. 89,130 N.W. 893 (1911) ; Hoyt v. Rosenberg, 182 P.2d 234 (Cal. App. 1947) ; cf. Harvey v. Colc, 159 Kan. 239, 153 P.2d 916 (1944) (child's conduct, whether as plaintiff or defendant, to be judged in light of his age, experience, intelligence, and education "at least until he reaches the later years of his minority").

14. Most of the commentators have taken this stand. See McCurdy, stpra note 10. So have the courts in the Charbonnean, Briese and Hoyt cases, supra note 13. Cf. RESTATENENT, TORTS \$283, comment $e$, and caveat (1934).

15. In Fill Transp. Co. v. Everett, 145 F.2d 746 (C.C.A. 1st 1944), the fedcral court sitting in New Hampshire was upheld in refusing to apply the rule of the Charbonneau case to a situation where a bus company was sought to be held vicariously liable for the conduct of its 18 year old bus driver. "The only reason for applying a lower standard of care when minors are concerned is to protect them from the normal consequences of their immaturity, not to protect anyone else therefrom. . ." This reasoning ignores the employer's right of recovery, over against the employee. But any objection on that score would be pretty theoretical. See notes 24,25 infra. 
authority and what there was involved what might be called play accidents rather than ones arising out of adult activities like driving a car. ${ }^{16}$ This is surely a very strong indication that minors were seldom sued, even when the stricter rule was thought to prevail-probably because they seldom had enough property to make suit worth while. This condition persisted through the early part of the motor vehicle era, when age restrictions and tests for driving were more lax than they are now. Today, of course, suits against minor automobile drivers are common, although there is nothing to suggest that they are being more widely sued than formerly in respect to their activities generally. The reason for all this is not hard to find-minor auto drivers are increasingly being covered by liability insurance. Now if that insurance were to any considerable extent bought and paid for by minors, the total picture would perhaps be changed but little, for the cost of their higher accident rate would still be cast on minors as a group. But this is not the case. A negligible amount of this insurance is paid for by minors. ${ }^{17}$ Generally they are covered by reason of omnibus coverage clauses ${ }^{18}$ in policies held by others (most often, no doubt, by their parents). Who then would pay any additional sum it might cost to hold infant drivers to an adult standard? This would depend on the rating practices of insurance companies. Until a few years ago no extra premium was charged where the policy normally covered minor drivers (as members of the named insured's family, etc.). The implication of this fact for our question is clear-the cost of the extra hazard caused by the shortcomings of youth was borne by the insured motoring public generally. That meant that any meaningful appraisal of the problem-whether in terms of morals or expediency-would have considered not the penalty or burden upon children (for that was non-existent) but rather the extent to which the motoring public and its beneficiaries ought to compensate those who are injured by the very serious extra accident hazard created by the youthful driver. ${ }^{10}$

Recent changes in rating practices have altered this situation some-

16. The Charbonmear case, 84 N.H. 501, 153 A. 457 (1931), was said to bring the total to three. Note, 79 U. of PA. L. Rev. 1153, 1154 (1931). In England, the point "seems never to have been decided," SALasond, LAy of TorTs 61 (10th ed. 1945).

17. Letter of John J. Hart, Assistant Secretary, Travelers Insurance Co., to author, dated Nov. 13, 1946.

18. These clauses extend coverage to "any person or organization legally responsible for the use of the [automobile] provided [its] actual use is with the permission of the named insured" (actual wording taken from Travelers Automobile policy). Sce SAwren, AUTOASOBILE LIABLITY InsURance 84 et seq. (1936).

19. The extra hazard is a serious one. See Lawshe, A Revrew of tre Literaturs Related to the Vartous Psychological Aspects of Higrway Safetr 32-3 (Purdue University Research Bulletin No. 2, 1939). For example, "the fatality rate in terms of miles for youths 16 years of age is about nine times as bad as it is for drivers aged 45 to 50 years." 
what. A lower rate is now given to a policy-holder whose car is not driven more than 7500 miles a year and who also has no one in his family under 25 who regularly drives it. If a man fails to meet either condition, he is charged a higher rate. ${ }^{20}$ Under this system the general tendency would be to distribute the cost of the extra hazards of youth (and note-not of minors only but of all drivers under 25) among their parents. What this amounts to is pretty much the same thing that would result from a universal vicarious liability of parents for the negligent driving of young people (without any real right of recovery over against the driver) and the real question is that of the extent to which burdens should be placed on that relationship and distributed among insured parents. ${ }^{21}$

What has been said incidentally throws light on the extent of legitimate public interest in insurance practices such as these, since they often determine the group among which some given aspect of tort liability will be distributed, and this is a very serious policy determination indeed.

Another field in which it is believed reasoning has proceeded on an altogether misleading and artificial basis is that of contribution among tort-feasors. As I tried to show by a study I once made, the net effect of the proposal for contribution would be to refine further the fault principle at the cost of giving insurance companies and large selfinsurers the opportunity to shift some of their losses onto the shoulders of uninsured individuals, so that a loss which had already been placed in the channels of distribution would be again thrown on an individual thus defeating pro tanto the social good that comes from the insurance principle. ${ }^{22}$ Somewhat the same thing is true in many situations where subrogation is now permitted. ${ }^{23}$ It is also theoretically true of claims for indemnity by those who have been held vicariously liable against

20. See note 17 supra; 40 BEST's No. 5, p. 12 (1939).

21. So far as play accidents go, just about the same possibilities of loss distribution exist through the modern Comprehensive Liability Policy. This was the case in Hoyt v. Rosenberg, 182 P.2d 234 (Cal. App. 1947). Letter from Cyrus M. Munroc, Esq., of San Diego, Cal., to the writer.

22. See James, Contributions Among Joint Tortfeasors: A Pragmatic Crificism, 54 HARv. L. REv. 1156 (1941).

23. See Shulmian \& James, Cases \& Materuals on Torts 125 (1942).

From the point of view urged in this article a somewhat similar problem was presented in an interesting recent case, United States v. Standard Oil Co. of Cal., 67 Sup. Ct. 1064 (1947). Here a soldier was injured by defendant's negligence and the Government sued defendant to get back money spent on the soldier's hospitalization and for his pay during the time he was incapacitated because of his injury. Recovery was denicd because the question was thought to be a matter of federal fiscal policy determinable by Congress, and Congress had refrained from providing any such remedy. Whatever department of the Government decides this policy question should, I believc, consider the fact that the Government is a far better agency to distribute losses than individuals or most businesses. 
the individuals whose negligence has been the ground of recovery. Fortunately such indemnity claims are practically never pursued by employers against employees. ${ }^{24}$ And in other relationships indemnity claims are generally precluded by the practical effect of modern liability policy provisions, where there is insurance. ${ }^{25}$

\section{III}

There is another way in which the fact of widely held insurance may have affected the practical operation of tort law. One of the traditional objectives of tort law has been to deter unreasonably dangerous conduct and to promote the taking of reasonable precautions. ${ }^{20}$ If an individual actor must pay for the cost of his carelessness out of his own pocket, the way in which this works is pretty plain to be seen. But how does insurance affect this? In what types of situations, if any, does it dilute the deterrent effect of liability upon the individual? Does this dilution tend to foster irresponsibility, or are there countervailing forces brought into play which promote accident prevention-perhaps even more than the fear of individual liability would do? In this inquiry one thing should be kept constantly in mind. Accident prevention is not the only aim of tort law, and tort liability is not the only incentive to accident prevention. If anything leads to more adequate care of injured people and their dependents, it may be justified on that ground alone. Those aspects of tort law in operation which lead to the compensation

An excursion into the realm of futile fantasy is found in some of the opinions in King v. Can. Pac. Ry., [1947] S.C.R. 185, where a somewhat similar problcm was solved by a resort to the metaphysics of proximate cause. Here the Government made payments to an employee under the Government Employees Compensation Act. There was no statutory subrogation, and suit was brought against the injuring third party on general principles. Recovery was denied, most of the judges reasoning that the compensation statute was an independent intervening cause. In sharp and refreshing contrast is the last paragraph of the opinion by Rand, $J$ : "One of the objects of the many forms of insuranee by way of compensation, pensions, etc., of these days is to ease the burden on the individual of consequences attendant upon the increasing hazards of complex social and industrial activities. But it would tend to reverse that policy to extend the established liability of the individual for the benefit of these collective interests. Liability is necessary for the essential standards of social conduct, but any enlargement of the field which in general rule our legal experience has mapped out should come from the legislature and not the courts." Id. at 201.

24. Whoever heard of a railroad company's pursuing such a claim against its engineer, for instance? Large companies certainly do not enforce such claims against their employees as a matter of general practice. There are, however, occasional instances where claims of this kind have been pushed.

25. See note 18 stpra. Under such a clause the insurance company would have to defend and indemnify the very person against whom its claim for indemnity would be pursued.

26. Thus it has been said, with only partial accuracy I think, "[t]he lav of torts exists for the purpose of preventing men from hurting one another. ..." SALso:to, LAW of ToRTs 13 (10th ed. 1945). See also id. at 18. 
and wide distribution of losses should be judged favorably, and extended, unless they actually bring about an increase in the accident rate. ${ }^{27}$ What then are the factors in the present situation which make for care or for carelessness?

In the first place it is obvious that fear of legal liability is not the only thing that spurs a man on to be careful. There are many situations, for instance, where one's negligence is likely to bring physical injury upon himself, as well as upon others. This is true of some of the commonest cases, such as driving an automobile, where the individual takes an active part in the situation at the time it is dangerous. In other types of situations, to be sure, a man's negligent conduct carries no real threat of bodily harm to himself either because of the nature of the case ${ }^{23}$ or because the man is acting through an agent. And, of course, a corporation cannot suffer this kind of injury. Even where the fear of personal bodily harm is absent, however, there are incentives to care. Accidents disrupt the normal processes of individual or business life. They often destroy valuable property. They are apt to cost money in collateral ways, quite apart from any question of possible damages. ${ }^{29}$ They may create bad public relations; or bad labor relations. Sometimes they threaten injury to a member of the family, or to a productive employee. And sometimes they involve the threat of criminal liability. Then, too, the simply humanitarian impulses furnish at least some people with a motive to take precautions for the safety of others. Another thing should be noted. In situations of employment, agency, and the like, there are usually two sets of incentives at work: for the employer, those last mentioned; for the employee, the risk of personal injury and also the fear of discipline for a job badly done. ${ }^{30}$

The factors referred to above operate quite independently of liability

27. This point of view is admirably set forth in Bowers, Compulsory Automonile Insurance 11-20, 110 et seq. (1929). Cf. Pollock, Torts 47 Excursus A (14th ed. 1939).

28. There are many situations where a man has carelessly created or has failed to remedy a dangerous condition (as in premises, machinery, products, etc.) which is far more likely to be encountered by others than himself.

29. In his address before the Torts Round Table Conference at the meeting of the Association of American Law Schools, held in Chicago on December 28, 1946, Mr. J. E. Brown, District Engineer of the Hartford Accident Indemnity Co., put the total estimated economic loss from accident for the year 1945 at over $\$ 5,000,000,000$. This included about half a billion dollars from fire losses. The figures were compiled from estimates of the National Safety Council and the National Bureau of Fire Underwriters.

It has been estimated that the "hidden" or "incidental" cost of accidents is four times as high as the direct costs. Heinrich, Management's Part in Safety, 40 Besr's No. 10, p. 37 (1940).

30. It is not suggested that all the factors referred to in this paragraph have the same force, or that they operate equally in all situations. Obviously that is not the case. But it is worth emphasizing that in nearly all cases there are strong reasons for carefulness quite apart from any question of liability. 
for civil damages. But the fear of such damages may afford some additional incentive to be careful, and the next questions are whether liability insurance appreciably dilutes this effect and whether it promotes or detracts from safety in other ways. The direct evidence on the first point is worth little. No doubt the protection given by insurance makes some individuals callous and every now and then a man will admit as much in his own case. But no one has measured how widespread such a reaction is. There are, however, certain facts which can be known and which shed considerable light on the net effect which the institution of liability insurance has on the matter of accident prevention. They are as follows:

1. Insurance has made direct contributions to the work of accident prevention. The wide combination of risks has brought together large aggregations of capital. This has put the insurance companies in a strategic position effectively to carry out programs to promote safety. They have done this both on an individual basis, and through such organizations as the National Conservation Bureau of the Association of Casualty and Surety Executives. Some such companies and organizations have very extensive technical and engineering staffs which devote all their time in well directed and expert efforts along this line. ${ }^{31}$

31. In his address cited note 29 stipra, Mir. Brown described in detail the organizztion and functions of the Safety Engineering Department of a large insurance company. The latter include research, inspection, and education. They are direeted towards loss prevention, loss minimization, risk selection, policy writing (i.e., development of factual information relating to classifications, rating bases, loadings and credits to enable underwriters and agents properly to write a policy); premium charges, retention of business, and development of new business (these last two, by giving and offering service, information, etc., to insureds and prospects).

Mr. Brown also described the organization and work of the National Conservation Bureau of the Association of Casualty \& Surety Executives. This has five divicions, viz: (1) industrial safety, (2) traffic engineering, (3) safety education, (4) special service division, (5) information and library division. The activities of these divisions cover a wide field and include the scientific study of accidents and formulation of safety rules and standards, the promotion of safety education with the general public, in the public schools, and in such centers as that at New York University, where safety is taught to teachers. The Bureau grants annual funds for scholarships at this center. It has also assisted in preparing pamphlets and textbooks (such as "MIan and the Afotor Car") which have been widely distributed. A similar description of the vork of this Bureau may be found in Mirphy, Cooperation, 39 Best's 444 (1938). The functions and accomplishments of the Underwriters' Laboratories, Inc., are described in 46 BEsr's No. 4, p. 37 (1945).

A sample of other references to the safety work of companies and organizations is as follows: 39 Best's 564 (1938) (Nebrasha and Oregon adopt safe driving courses in high schools); id. at 968 (1939); 48 Best's No. 3, p. \&0 (1947) (announcements of new safety publications for wide public distribution); id. at 69 (1947) (reference to safety advertisements of one company); 47 BEst's No. 12, p. 35 (1947) (new device for testing drivers invented by one company); 48 Best's No. 3, p. 69 (1947) (article urging agents to "improve [their] theater risk" by studying its fire and casualty hazards, with conerete suggestions for their improvement); 47 Besr's No. 11, p. 85 (1947) (describing cooperation with President's Highway Safety Conference). 
This is the sort of service that only the largest industrial concerns could perform at all effectively if they had to do it for themselves. ${ }^{32}$ It includes analysis of past accidents generally, and of specific current accidents to determine whether they disclose defects in supervision, equipment, or in the habits or states of mind of workers. It also includes inspection of equipment and survey of operations to discover in advance defects, practices, personal factors and the like which are dangerous, and the working out of devices, rules, and arrangements which will minimize the danger. In some lines of insurance, the amount of money spent on accident prevention exceeds the amount paid for losses. ${ }^{33}$

The insurance companies and organizations have also cooperated actively with other groups engaged in safety promotion, and have contributed materially to the education of the general public along this line. ${ }^{34}$

2. Insurance companies can and do adjust their rates and select their risks so as to furnish an incentive towards safety. Overall rates in any field reflect overall losses. And the latter are, of course, very much affected by the accident rate (among other factors)..$^{36}$ Probably there is a rather vague general realization of this relationship and it may afford some slight motive to be careful, but the effect of any individual's conduct on the general rate structure is so little, that the motive can hardly be strong.

There are several ways, however, in which rating practices have rewarded or penalized individual assureds for their own safety records.

32. In Steidle, Self Insurance for the Average Company, 46 Best's No. 1, p. 47 (1945) the author, Manager of the Insurance Department of the Bethlehem Steel Corporation, stresses the engineering loss prevention service afforded by the insurance company as a factor seriously to be considered in deciding whether a company should become a self-insurer.

33. In the case of the Hartford Steam Boiler Inspection \& Insurance Co., for instance, the ratio (for 1936-1945) of net losses incurred to underwriting income carned was $23.9 \%$, while the ratio of expenses incurred to underwriting income earned was $78.7 \%$. The analogous ratios for a group of 100 casualty, surety, and miscellaneous companies were $45.6 \%$ and $46.9 \%$ respectively. The Spectator Property Insurance Review, June 13, 1946, pp. 14-5 (hereinafter cited as Spectator). For the same company in 1937 the ratio of losses paid to premiums written was $14.7 \%$; the ratio of expense for inspections to premiums written was $23.42 \%$. 39 Best's 570,571 (1938).

A recent $18 \%$ rise in elevator bodily injury liability rates reflects increases in inspection costs despite reductions in losses. 48 BEST's No. 2, p. 45 (1947).

34. See articles cited note 31 stupra.

35. Before the war, for example, declining accident rates in New York City over a number of years led to progressively lower premiums for automobile liability insurance. 39 BEsT's 632 (1939). On the other hand the sharply rising automobile accident rate, over the whole country, is one of the factors most stressed in connection with the rises in rates since the war. See, for example, Spectator, June 13, 1946, p. 49 ; 47 BEst's No. 11, p. 17 (1947). In other fields, declining accident rates have been attended by premium reductions for liability insurance. 48 BEsr's No. 2, p. 45 (1947). Cf. Sawyer, Compensation Rates and Safety, 42 Best's No. 2, p. 47 (1941). 
Large risks are being increasingly written on an experience basis so that the rate for each more or less reflects the loss experience encourtered on that risk itself. ${ }^{36}$ And before the war there was in wide use one form or another of a safe driver reward plan for individual automobile owners. ${ }^{3 \pi}$ These have been pretty generally abandoned, largely it seems because of the administrative difficulties they entailed. ${ }^{33}$ But in this and other fields, companies do exert an influence for safety by rejecting risks which have had bad experience or accepting them only at higher premiums. ${ }^{39}$

3. Great strides toward safety have been made in many fields where insurance is widely held. This is notably true in the case of elevators, boilers and machinery. Here, as one writer puts it, "the [insurance] rates have long been based largely upon the cost of accident prevention. The result of that work is a degree of safety little short of phenomenal." ${ }^{40}$ And industrial accidents generally have sharply declined in the course of a generation. During the first World War there were in this country some 36,000 industrial fatalities a year. During the last war, although output was stepped up as never before, annual industrial deaths were held to about 17,000. ${ }^{41}$ In the field of aviation, some of the pioneer safety work has been claimed by insurance companies. ${ }^{42}$

Automobile accidents, on the other hand, continue to occur at an alarming rate. ${ }^{43}$ Probably here, in the case of the individual car owner

36. The older method of adjusting premiums to the insured's efforts towards eafety was on the basis of physical equipment and condition of the plant. Brown, supra note 29. More modern plans include the so-called guaranteed-cost and various kinds of retrospsetive rating methods. For descriptions of some of these, see 47 Besr's No. 11, p. 29 (1947) ; id. No. 6, p. 25 (1946) ; 39 Besr's 457 (1938).

37. See Sawyer, Fronticrs of Liabilify Insurance, 39 Best's 439 (1938); Collins, Rating Problems, id. at 454 ; id. at 560 (preferred risk rating in New York). Cf. id. at 970 (1939) (describing intensive advertising campaign by National Bureau of Casualty \& Surety Underwriters on behalf of safe driver reward plans).

38. 43 Best's No. 7, pp. 13-4 (1942). See also Blanchard, Compulsory Insuranee in Massachisetts, 3 LAw \& Contear. Prob. 537 (1936). At least one company, however, still offers a merit rating. See advertisement, Spectator, Mfarch 28, 1946, inside back cover.

39. J. E. Brown pointed out in his address, stpra note 29 , that one function of a company's safety engineering department is to select risks. See also 46 BEsr's No. 5, p. 31 (1945) (insurance has contributed to air safety by selections of risks); Spectator, Jan. 24, 1946, p. 10 (description of how undesirable auto liability risks are handled under the British Columbia assigned risk plan). Cf. Blanchard, Comprulsory Itsuransec in alossachusctts, 3 LAw \& CONTEMr. Prob. 537, 551 (1936). Interestingly enough the loss esperience with the assigned risks in New Hampshire has been "far better than on normal risks". Rouillard, Experience in New Hampshire, 41 Best's No. 11, p. 19, 76 (1941).

40. Sawyer, Retooling Casualty Insurance, 45 BEsr's No. 9, p. 37 (1945). Sce also note 33 sitpra.

41. Hall, Everybody's Job, 47 Besr's No. 11, p. 85, 96 (1947); ef. 39 Besr's 749 (1939).

42. Perry, Aviation Insurance, 46 Best's No. 5, p. 31 (1945).

43. Accionnt Facts (1946 ed.); Spectator, June 13, 1946, p. 49 ; 47 BEst's No. 1, p. 17 (1947). 
at any rate, the insurance companies have less effective leverage to implement their safety campaigns than in the case of larger risks where many operations are under the control of a single insured whose premiums vary with his loss experience. ${ }^{44}$ On the other hand, motor accident statistics contain no indication that the presence of insurance makes accident rates go up. Indeed, accident records are better on the whole in states where there is a relatively high proportion of insured owners. ${ }^{45}$

The foregoing facts point to the following inferences: (a) in many fields the practical operation of liability insurance has been definitely to promote safety rather than foster carelessness, (b) in fields such as automobile and personal liability insurance the insurance companies have less effective means at their disposal to promote safety and their success in doing so is less readily demonstrable. On the other hand, there is no significant evidence to show that insurance protection leads to increased carelessness. ${ }^{46}$ And the insurance companies are engaging in these fields too in efforts to promote safety which in the long run

44. In the case of fleet operations of motor vehicles, insurance companies have worked out systems for driver selection and training, for safety incentive plans, for the selcction and maintenance of equipment, and the like. Brown, address, supra note 29 . See also Spottke, Truck Insurance, 47 BesT's No. 6, p. 25 (1946).

45. See Shulman \& James, Cases \& Materials on Torts 708 (1942), indicating the relatively good record of Massachusetts for motor vehicle fatalities both before and after the effective date of her compulsory insurance law. More recent statistics indicate that the enviable Massachusetts record has continued. Accroent FActs (1946 ed.) shows that for the period 1943 to 1945 , only the District of Columbia and three states had a lower fatality rate record than Massachusetts, $i d$. at 61 , while her relative standing for 1915 alone was even better, id. at 51. It is true that the reported non-fatal accidents showed an increase after compulsory insurance. See, e.g., 40 BEST's No. 7, p. 22 (1939). But there is good reason to believe that this was only a paper increase caused by the more complete reporting under the new law, and that the record of fatalities is a far more accurate index of what happened. And of course the accident rate for the country as a whole showed a marked increase during the decade after Massachusetts adopted compulsory insurance. See Accident Facts 62 (1946 ed.).

Another state where there was a marked increase in the proportion of insured cars is New York. It is estimated that in 1942 only about $30 \%$ of her cars were insured, and that this figure jumped to $75 \%$ in 1943 after passage of her Safety Responsibility Law and is now higher. Veness, Safety Responsibility, 48 Best's No. 2, p. 37-8 (1947). Thereafter, despite an increase in the number of accidents and of automobile registrations, the fatality rate dropped to 8.4 per 100 million miles of vehicle travel, the first time ever recorded under 10 . Id. at 39.

In general the highest proportion of insured cars is to be found in the Middle Atlantic and New England states. See Shulman \& James, Cases \& Materrals on Torts 617, 618 (1942). And these states have among the most favorable motor vchicle fatality records in the country. On the other hand a group of central north western states also has a good accident record and a relatively low proportion of insured cars. ACCIDENT FAcrs 51 (1946 ed.).

46. The same conclusion is reached in Blanchard, Auto Instrance and the Traffic Problem, 40 Besr's No. 3, p. 15 (1939). 
will probably have material effect. All in all, therefore, it is safe to conclude that the benefits of social insurance which come even under the present law through the operation of liability insurance are not offset by any encouragement of irresponsibility. On the contrary, there has probably been some concomitant net gain in accident prevention. Moreover, there is no reason to expect any threat to safety from further extensions of the insurance principle in the field of accidents.

\section{IV}

A third important effect which insurance has had on the practical operation of tort law has been produced by the development of policy coverage and of other provisions in the policy. To a limited extent this has been brought about by statute, but in no small measure it has come about through progressive business practices on the part of the companies themselves. These developments have been along two lines: they have increased the chances of compensation to the victim in cases where someone is legally liable to him for damages; and they have started to open up possibilities of compensation even where there is no liability under existing rules of tort law.

Where the insured is a person legally liable, the fact of his insurance against that legal liability has always, as a practical matter, increased measurably the chances that any judgment or settlement agreement would be satisfied. But the older type of policy was one of indemnity. This meant that it was not available at all to the victim directly, and that any legal liability under it was conditioned on fulfillment by the insured of all conditions in the policy and discharge by him of legally established liability for the injury. Thus it could be defeated by the insured's bankruptcy, insolvency, or inability to pay, by fraud in his application for insurance, or by his breach of the policy conditions. And only the insured himself, for whose sole protection the insurance contract was regarded as existing, could bring any legal compulsion to bear upon the company. The possibilities of collusive abuse inherent in this system led to legislative action in some states. ${ }^{47}$ Partly in response to this, the standard policy of today has in all cases changed this picture in a very material respect. This policy is an undertaling to pay (within policy limits) the legally established liability of the insured without regard to his having discharged it and in spite of his financial inability to do so. Moreover the injured victim is given a direct right of action against the insurer, once he has established the insured's liability by judgment or agreement of all parties (including of course the company). ${ }^{43}$ Under this standard clause, however, the

47. Vance, Handbook on the Law of Insurance 6S4-S (1930); Sawrer, AutoMOBLE LIABLITY InSURANCE 2-3 (1936) (pointing out that even under strict indemnity policies, the claim practice of the companies had for years been the same as under those agreeing "to pay").

48. Sawyer, AutontobiLe Liability Insurance Appendix A (1936). 
rights of the injured party are defeated if the insured fails to perform the conditions of the policy. ${ }^{49}$ Some statutes have gone further and have taken away or modified even such defenses. Thus the Massachusetts compulsory insurance law provides that no statement made by or for the insured and no violation of the terms of the policy by him shall defeat or avoid the rights of the accident victim against the insurance company. ${ }^{50}$ And some financial responsibility laws have a similar provision. ${ }^{51}$

In many cases the actual tort-feasor has no substantial property and has bought no insurance against his liability. Where that is so, compensation for the victim depends on his being able to hold someone else such as the maker or owner of machinery involved, the employer, the parent, or an insurer who has come into the picture by contract. Originally, liability insurance contracts covered only the legal liability of the person who bought the policy. ${ }^{52}$ In the case supposed, therefore, the injured person's chance of getting actual recovery was limited by such doctrines as vicarious liability, negligence in making or maintaining the machine, negligence in entrusting a machine to incompetent persons, and the like. The law was not, however, altogether unresponsive to the quest by accident victims of a financially responsible defendent, and the limits of the doctrines just mentioned underwent some expansion. There were significant judge-made developments. Starting with the general rule that parents were not vicariously liable for the torts of their children, the courts in this motor age of ours devised out of curious fiction the family car doctrine. ${ }^{53}$ There was also an occasional instance of liberal judicial presumption in cases of bailment. ${ }^{54}$ And at least one court, without the aid of statute, was willing to hold the auto owner for the negligence of any driver to.whom he had entrusted its operation on the theory that it was a peculiarly dangerous instrumentality. ${ }^{55}$ Moreover, there were many legislative extensions of vicarious liability, the most far-reaching of which are statutes like those in New York and California making the owner liable for the negligence of any-

49. For a list of conditions, see SAwYER, op. cit. sitpra note 48, at 294. Those probably most often called into play are the ones requiring notice of accident and notice of suit, and that requiring the assistance and cooperation of the insured.

50. Mass. Ann. Laws, c. 175, §113A (1942).

51. For example N.Y. Laws 1942, c. 249(i) (1) ; PA. Stat. ANs., tit. 75, §1277.21 (f) (1) (Purdon, Supp. 1946) ; cf. Travelers Mut. Cas. Co. v. Herman, 116 F.2d 151 (C.C.A. 8th 1940).

52. SaWyer, Autonobile Liability Insurance 84 (1936).

53. Harper, Law of Torts $\$ 283$ (1933) ; Prosser, Torts 500 (1941).

54. See authorities collected in Shulman \& James, Cases \& Materials on Torrs 673 n.20 (1942).

55. Southern Cotton Oil Co. v. Anderson, 80 Fla. 441, 86 So. 629 (1920); Sce Prosser, Torts 447, 500 (1941). 
one operating a motor vehicle with the express or implied consent of the owner..$^{56}$

In large part, however, these doctrinal developments are frontiers of the past. Some of the most important and widely held types of policies cover as "additional insureds" many people who would be beyond all but the most extravagant reaches of vicarious liability. ${ }^{57}$ Thus the child who kicks his schoolmate across the aisle is limelf protected by his father's comprehensive personal liability policy. And the mere borrower of a car is himself covered by the owner's insurance "s (though only the most advanced type of statute would make the owner liable). And omnibus coverage clauses will probably be offered increasingly on other types of risks. ${ }^{59}$ Another provision which is becoming increasingly popular has a similar tendency to extend the coverage of a single policy, viz. the "drive other car" clause. As it is commonly written in automobile liability policies, this covers the named insured and spouse while operating any other car. ${ }^{60}$ Foreseeable future developments of this clause are extensions of it to cover other members of the named insured's household ${ }^{61}$ and introductions of it into other fields. ${ }^{62}$

Still another development which also gives greater assurance of compensation to accident victims is the fairly recent medical payments provision. As now written in automobile liability policies, this provides limited payments to injured occupants of the insured's car (or of another car driven by the insured or spouse under a "drive other car" clause) to cover medical or funeral expenses. Insurance companies are introducing this kind of coverage widely throughout the liability field, ${ }^{\text {os }}$ and already, progressive insurance men are urging extension of it to include all victims of an accident in which an insured or his car is involved. ${ }^{64}$ In a vital respect, this goes even further than anything heretofore mentioned: it provides for payment without regard to fault.

56. CAL. Vehicle CODE 1943, §402; N.Y. Vegicle \& Traffic LAw 1941, § 59.

57. Notably the automobile liability and the comprehensive personal liability policies.

58. See note 18 supra.

59. It is now being written, for example, on an optional basis, in products liability insurance. 46 BEST's No. 5, p. 70 (1945).

60. See, e.g. 40 Best's No. 2, p. 24 (1939).

61. 46 Best's No. 5, p. 27 (1945). p. 29.

62. "Fly-other-plane" clauses are already being written. Spectator, Feb. 14, 1946,

63. Liability Revisions, 48 Best's No. 2, p. 45 (1947) (general revisions announced by National Bureau of Casualty \& Surety Underwriters, effective June 2, 1947, include medical payments program applicable to all risks classified and rated in the owners', landlords', \& tenants' liability manual. Such coverage may also be written for manufacturers' and contractors' liability, etc.); Spectator, Feb. 14, 1946, p. 29 (noting the writing of such coverage in aircraft liability insurance).

64. Address of Alfred E. Spotthe of the National Bureau of Casualty \& Surety Underwriters, at annual meeting of R.I. insurance agents, Providence, R.I., Oct. 23, 1944.

The popularity with insurance men of this type of coverage is prempted in part 
This may indeed soon bring in a limited absolute liability with assured compensation in all accident cases where there is insurance.

The upshot of these developments in insurance policies may be roughly summarized thus:

1. There is a tendency-which has in large part been realized-to cover any driver of an insured car.

2. There is a tendency - at least partially realized-to cover members of the insured's family no matter what car they drive.

3. A movement has gotten well under way to provide for limited payments on account of medical expenses for accident victims, where there is insurance-without any regard to fault.

4. There is a tendency-at least partially realized-to give accident victims less qualified and more direct access to the insurance itself (where there is legal liability).

\section{$\mathrm{V}$}

The settlement practices of insurance companies constitute another factor which has a great impact on the actual operation of tort law today. The vast majority of accident claims never get into any stage of litigation; only an infinitesimal proportion of them ever come to trial. The "law" that directly governs the disposition of most tort claims, then, consists in these practices. The legal rules affect most cases only to the extent that they are reflected in the process of settlement.

The results of the settlement process (and other aspects of compensation for automobile accident victims) were studied under the auspices of the Columbia University Council for Research in the Social Sciences with the aid of the Yale Law School. An effort was made to get a fair cross-section of personal injury cases, without any regard to questions of fault or legal liability: 65 On the point considered here, it was found that some payment is made in about $85 \%$ of motor vehicle accident cases involving personal injury or death, where there is insurance; that where injuries are slight, payment on the whole is prompt and adequate, but that both promptness and adequacy (from the point of view of compensation alone, without regard to fault) declined with the seriousness of the loss. ${ }^{66}$ It is hard to tell in what proportion of automobile accident cases there would be liability if an omniscient tribunal were to apply the textbook rules of tort law with rigid disregard for popular

by public pressure towards social insurance in this field and the fear for "private insurance if the state takes over any part of the compensation." Sawyer, Fronticrs of Liability Insurance, 39 BEsT's 439, 440 (1938).

65. The procedure was such that the committee conducting the study felt justified in applying to the country at large the conclusions derived from its data. CoLumbis Rerort 53.

66. COLUMBia Report c. 5. 
prejudice or sociological trends. But it would certainly be far below $85 \%$. The Committee on Insurance of the National Conference on Street and Highway Safety, for instance, reported that $32.7 \%$ of these accidents were caused by careless or reckless automobile driving; $29.3 \%$ by a careless pedestrian; $18.7 \%$ by both parties jointly. The conclusion from all these facts is that, so far as the making of some payment goes, there is a closer approach to absolute liability in practice than in theory. In other words, wherever there is insurance there is to this extent a closer approximation to the objectives of social insurance in fact than the doctrines of tort law would lead one to suppose.

Several factors contribute to the result just described. Some of them are altogether non-legal. To an insurance company any claim has a nuisance value which is roughly measured by the amount of money it would take to prepare the case for trial and defend it..$^{c 3}$ Moreover, it is a matter of good public relations and salesmanship for a company to settle claims and do it promptly. ${ }^{69}$ People who are already insured do not want to be bothered with suit or any of the trouble it takes to resist a claim, and claimants as a class include many prospective insurance buyers. Further, prompt disposition of claims enables the company to keep down the reserves for contingent liability it must carry on its books. ${ }^{70}$

To the extent that the settlement of so high a proportion of claims represents legal factors, it probably reflects for the most part broad general trends in the law of torts, rather than specific rules of law. Today between two-thirds and three-quarters of the jury verdicts in tort cases are in favor of plaintiffs. ${ }^{11}$ That means that if a plaintiff can

67. Report of Conamttree on Insurance, Natronal Comference on: Strenet \& Highway Safety 11 (1924). See also Bowers, Costrutsony Autossonms Insura:ice 73 (1929). In ACCIDENT FACTs (1946 ed.) are given tables showing an estimate of the percentages of cases of various types in which there was a driver violation. These show that drivers were not reported violating in about two-thirds of the cases involving injury to a pedestrian. In other cases the proportion of driver violations was higher. Id. at 56-7. It is said that two out of every three pedestrians lilled were either violating a traffic law or committing an unsafe act. Id. at 59 .

68. There are two schools of thought among insurance claim men as to whether doubtful cases should be settled for their nuisance value, but certainly the practice of settling on this basis is very extensive. Auto Liability Suits, 41 Best's No. 5, p. 15 (1940); Sawyer, Casualty Insurance Litigation, 40 BEsT's No. 6, p. 21, at 71 (1939).

Sometimes the principle of the nuisance value has been used by insurance companies in reverse, as by refusing to pay full compensation in small property damage cases (even where there is clear liability) on the theory that few claimants will go to the trouble and expense of pursuing such claims to get full damages for them. Mrany insurance men deplore such a practice. See Spectator, May 23, 1946, at p. 17; Van Orman, The Claim Afers and Public Relations, 47 Best's No. 4, p. 19 (1946).

69. Ibid.; cf. Jainsen, The Clain Picture, 41 Best's No. 10, p. 21 (1941).

70. See Sawyer, Casualty Insurance Litigation, 40 Best's No. 6, p. 21, at 70 (1939).

71. Judictal Statistics of the Work of the Supreare Cours of New Yoas, First Judictal Dept. (1930-1935) ; Clark \& Shulsrari, A Study of Lay Adrmisisma- 
get his case to the jury, the chances are pretty heavily in favor of his getting some recovery. To put it in claim parlance, any case that can get to the jury has a settlement value. Probably, therefore, only those legal rules which will effectively keep a case from going to the jury play a dominant part in the settlement process. And the trend in tort law during recent years has been very definitely away from such rules. ${ }^{72}$

When one turns from the fact of payment to the question of its adequacy to cover losses, the picture changes. From its study the Columbia committee came to this conclusion:

"To sum up, this analysis indicates that the payments do not increase in proportion to the losses sustained; temporary disability cases with small losses are considerably overpaid, those with larger losses are slightly overpaid, while permanent disability cases of earners-the class with the largest losses and greatest need-receive just about enough to meet the losses incurred up to the time of investigation and get nothing to apply against the continued medical expense or wage loss resulting from their impaired earning ability." 73

This is a grave defect indeed in our present system, especially in the eyes of those who accept the objectives of social insurance. It comes largely from non-legal factors. As one writer puts it, "[a]t present the economic consequences of motor-vehicle accidents are distributed, in theory, on the basis of fault; in fact, on the basis of chance, trading, and the relative resources of claimants, motorists, and insurance carriers." 74 Since most motor accident victims are from the lower income groups they are as a class not in a strong bargaining position. To make matters worse, the greater the injury, the loss and the need, the weaker the victim's bargaining position becomes and the less able he is to wait for the outcome of the tedious process of litigation. ${ }^{75}$ As long as the

TION IN CONNECTICUT 74, 213 (1937) ; Columbia Report 90. Added significance is given to the proportion by the fact that defendants try especially hard to settle cases where liability is clear.

72. Nixon, Changing Rules of Liability in Automobile Accident Litigation, 3 LAw \& Contenrp. Prob. 476 (1936); Searl, Automobile Liability Law Development and Trend, 39 Best's 583 (1938) ; James, Accident Liability: Some Wartime Developments, 55 YALE L.J. 365 (1946).

73. Columbia Report 92.

74. Blanchard, Auto Insurance \& The Traffic Problem, 40 Best's No. 3, p. 15-6 (1939). The Columbia committee's conclusion was the same. Columbia Report 200.

75. This is the conclusion of the Columbia study. One who was engaged in that study described the situation thus: "But the great disadvantage to the injured is that while the buyer of a waiver of future claims is not anxious to buy at all unless the horizon is really threatening, the seller must sell to this buyer or none at all. His costs have been forced from him, he must recoup what he can. And, if the outlay has been serious, the injured often needs money and at once. In Connecticut $25 \%$ of the injured had a total family income of $\$ 1,500$ a year and $59 \%$ less than $\$ 2,500$. 31\% were either sole family 
matter of compensation is left to be fixed largely by bargaining, the tendency will be for this fact to overshadow considerations of theoretical liability. ${ }^{76}$

\section{Conclusion}

The accident problem of our mechanical age calls for two things: accident prevention and the compensation of the victims of accidents that do happen. As for that branch of the law which is concerned with civil damages or their equivalent, it is doubtful whether it contributes very much to accident prevention. But if it does, that contribution will not be diminished by further steps towards assurance of compensation and widespread distribution of the loss; indeed such changesor at least some of them-may well further the cause of safety. The main job of accident law is, therefore, to promote the well-being of accident victims if this can be done without imposing too great a social cost in other directions. It is the writer's conclusion that a system of social insurance can do this. The expressed doctrines of tort law are not well adapted to such an end. They are horse and buggy rules in an age of machinery; and they might well have gone to the scrap heap some time ago had not the tremendous growth of liability insurance and the progressive ingenuity of the companies made it possible to get some of the benefits of social insurance under-or perhaps in spite ofthe legal rules. What we have as a result is only a partially satisfactory solution. Many who cause accidents are still financially irresponsible and not covered by insurance. Even where this is not the case, many needy victims are still barred because of the fault principle, and many others fail to get what they are legally entitled to under existing law, because of the weakness of their bargaining position. ${ }^{7}$ Even if the

supporters or one of two. Such a situation leaves little leeway for unforeseen emergencies. The family doctor may wait, the landlord be generous, the grocer, up to his limited means, give credit. But a nurse is not a capitalist and needs her wage at once, a specialist is not the family doctor, the need for coal and light, medicine, special sicls foods and some unavoidable necessities of family living goes on. The result is that the families most in need of compensation can often least afiord to hold out for an adequate prica, i.e., a price commensurate with expenditure and as great as those who can afford to wait might obtain." Corstvet, The Uncompensated Accident and Its Conscannices, 3 LAw \& Conteur. Pros. 466, 468 (1936).

76. It is true that progressive insurance men are urging a more liberal attitude towards larger claims. See Spectator, May 23, 1946, p. 16; cf. Sawyer, Castal/y Insuronce Litigation, 40 Best's No. 6, p. 21, at 71 (1939); Van Orman, The Claim Man and Public Relations, 47 Best's No. 4, p. 19 (1946).

77. The view has sometimes been taken that if the full sweep of modern negligence law be realized, "it is generally unnecessary, in order to do justice to a plaintiff, to adopt the doctrine of acting at peril." Smith, Tort and Absolute Liabilify-Suggested Chonges in Classification, 30 HARv. L. Rev. 409, 414 (1917). That might conceivably be true as between negligence and absolute liability as administered under the present law of torts. But this glaring defect (mentioned in the text) in the present system shows a wide discrepancy between it and a full scheme of compensation, or social insurance. 
present system improves, it is not likely to be permanent, but rather to yield to a system of full social insurance with the government playing a role at least as important as that which it plays in workmen's compensation. The question of how long the present system will endure is likely to depend on how progressive and far-sighted the insurance companies are, and on the success of such legislative half-way measures as compulsory insurance, financial responsibility laws, and the like. While it does endure, no analysis or appraisal of tort problems or tort law in the accident field can be really helpful unless it takes full account of the fact and operation of liability insurance. The present article is simply intended to suggest ways in which this may be done. . 